\title{
Beryllium Content of the Normal Human Prostate Gland: A Systematic Review
}

\section{Vladimir Zaichick*}

Radionuclide Diagnostics Department, Medical Radiological Research Centre, Russia

*Corresponding Author: Vladimir Zaichick, Radionuclide Diagnostics Department, Medical Radiological Research Centre, Russia.
Received: February 02, 2021

Published: March 16, 2021

(C) All rights are reserved by Vladimir

Zaichick.

\section{Abstract}

The knowledge concerning etiology and pathogenesis of most prostatic malfunction and pathologies is very limited. Notwithstanding advances in medicine, the diagnostics of benign hypertrophic and cancerous prostate has relentlessly increased in intricacy and inconsistency. A supposal has been made that beryllium (Be) level in prostate gland may aid in resolving these problems and especially as a biomarker of prostate cancer. As a result in many studies the normal prostatic Be measurements have been made. In present review we analyze data published concerning Be prostatic levels in healthy persons. In total 2161 papers in the literature of the years dating back to 1921 were authenticated in such databases as: PubMed, Scopus, the Cochrane Library, Web of Science and ELSEVIER-EMBASE. Obtained information was subject to an extraction both the Be content ranges and means. In such a way the discrepancy of published Be level of normal glands was estimated. From the articles analyzed, 14 were separated for the impartial evaluation of results from their 645 healthy subjects. Prostatic Be contents (on a wet mass basis) spanned the interval from 0.000155 $\mathrm{mg} / \mathrm{kg}$ to $<0.03 \mathrm{mg} / \mathrm{kg}$ with $0.000168 \mathrm{mg} / \mathrm{kg}$ as the median of their means. The results covered a wide range of values and the sample was small, hence it is desirable that further investigations with strong quality control of results be performed.

Keywords: Beryllium; Human prostate gland; Normal prostatic tissue; Biomarkers.

\section{Abbreviations}

PCa: Prostate Cancer; BPH: Benign Prostatic Hyperplasia; TE: Trace Element; IARC: International Agency for Research on Cancer; US EPA: U.S. Environmental Protection Agency; ICP-MS: Inductively Coupled Plasma Mass Spectrometry.

\section{Introduction}

Amongst the many pathological prostatic conditions, prostatic carcinoma (PCa), chronic prostatitis and benign prostatic hyperplasia (BPH) are very frequently encountered, especially in the elderly [1-3]. Their causes and pathogenesis are poorly understood.
Moreover, despite biomedical advances, the the diagnostics of benign hypertrophic and cancerous prostate has become gradually more complicated and contentious. An improvement of this situation, especially recognition of relevant risk factors and the disorders' etiologies can allow great reduction in the incidence of these prostatic disorders.

In our previous investigations the participation of trace elements (TEs) in the function of the prostate gland was indicated [415]. It was also found that content of TEs in prostatic parenchima, including beryllium (Be), can play a noticeable role in etiology of PCa [16-21]. Furthermore, it was shown that the alterations of 
some TE contents and $\mathrm{Zn} / \mathrm{Be}$ content ratios in prostate parenchima can be helpful as bio-indicators [21-28].

For the first time low levels of Be in human prostatic tissue $(<0.03 \mathrm{mg} / \mathrm{kg}$ of wet tissue) was indicated in studies published almost 60 years ago [29]. This finding allowed deduce inference that the prostate can accumulate Be, since the content of metal in glands was at least one order of magnitude higher the blood reference content $(0.001 \mathrm{mg} / \mathrm{L})$ [30]. Moreover, experimental and epidemiological results identified that Be should be considered as genotoxic carcinogens [20,21,31,32]. In accord with the International Agency for Research on Cancer (IARC) and U.S. Environmental Protection Agency (US EPA), Be is classified as Group 1 and Group A human carcinogens, respectively [33,34]. These materials facilitated more extensive considerations of the Be level of prostatic tissue of healthy persons, as well as of patients with different prostatic disorders, including hypertrophy and malignancy.

The impacts of TEs, including Be, are depended on their level in tissues and fluids. Recorded observations range from a deficiency, through normal function as biologically active components, to an imbalance, when excess of one element interferes with the function of another, to pharmacologically active levels, and finally to toxic and even life-threatening contents [35-37]. In this context, until now there are no data on any biological function of Be in organisms, but a lot of publications testify to adverse health effects in different organs or tissues, including malignancy, of exposure to low doses of this metal and its compounds [21,30,32,33,38]. However, it is as yet incomprehensible what precise mechanism is responsible for Be carcinogenicity [21,38].

By now, a few publications have presented the level of Be content in tissue of "normal" and affected prostates. However, subsequent research works has been considered necessary to provide a practical reference data of Be contents in "normal" and affected gland, as the results of various investigations demonstrate some distinctions.

Our review addresses the importance of Be contents in prostate as an indicator of the gland's condition. Therefore, we systematically reviewed all the available relevant articles and performed a statistical analysis of Be level of "normal" prostates, which may provide valuable insight into the etiology and diagnosis of organ diseases.

\section{Materials and Methods}

Data sources and search strategy

Aiming at finding the most relevant publications for this review, a thorough comprehensive web search was conducted by consulting the PubMed, Scopus, the Cochrane Library, Web of Science and ELSEVIER-EMBASE databases, as well as from the personal archive of the author collected between 1966 to 2020, using the key words: prostatic trace elements, prostatic Be content, prostatic tissue, and their constellation. For example, the search terms for Be content were: "Be content", "Be level”, "Be mass fraction", "prostatic tissue $\mathrm{Be}$ " and "Be of prostatic tissue". The language of the paper was not restricted. The titles from the search results were examined thoroughly and determined to be acceptable for potential inclusion criteria. Also, references from the selected publications were evaluated as further search instruments. Relevant references noted for the each selected paper were also examined for inclusion.

Eligibility criteria

Inclusion criteria

Only articles with quantitative results of Be prostatic level were accepted for further examination. Publications were accepted if the control groups were healthy men with no history or evidence of urological or other andrological disease and Be contents were measured in samples of gland.

\section{Exclusion criteria}

Articles were excluded if they were case reports. Investigations involving persons that were Be occupational exposed, as well as subjects from Be contaminated regions were also excepted.

\section{Data extraction}

A standard extraction of results was applied, and the following available variables were taken out from each article: method of Be measurement, number and ages of healthy subjects, sample preparation, mean and median of Be content, standard deviations of mean, and range of Be contents. Abstracts and whole text of papers were reviewed independently, and if the results were different, the texts were checked once again until the distinctions were eliminated.

\section{Statistical analysis}

Results of all investigations were stitched together based on means of Be contents in "normal" prostate. The papers were exam- 
ined and "Median of Means" and "Range of Means" were exploited to evaluate heterogeneity of Be levels. The impartial analysis was performed on results from the 14 articles, with 645 persons.

\section{Results and Discussion}

Data on Be contents in prostatic tissue in normal and pathological conditions are of obvious interest, not only to clarify the etiology and pathogenesis of prostatic disorders, but also for their diagnosis, particularly for malignancy detection and PCa risk prognosis $[27,28,35]$. Thus, it dictates a need for reliable values of the Be contents in the prostate of apparently healthy persons, ranging from young adults to old men.
Possible articles relevant to the keywords were retrieved and screened. A total of 2161 papers were primarily obtained, of which 2147 irrelevant publications were excluded. Thus, 14 articles were ultimately selected according to eligibility criteria that determined Be contents in "normal" glands (Table 1) and these 14 studies [9,13,14,27,29,39-47] arranged the material on which the review was founded. A number of results for Be contents in the cited references were not expressed on a wet mass basis. However, we recalculated these results using the medians of published values for water - 83\% [48-51] and ash - 1\% contents (on a wet mass basis) in "normal" prostates of adult males [50,52-54].

\begin{tabular}{|c|c|c|c|c|c|c|}
\hline \multirow{2}{*}{ Reference } & \multirow{2}{*}{ Method } & \multirow{2}{*}{$\mathbf{n}$} & \multirow{2}{*}{$\begin{array}{c}\text { Age } \\
\text { range } \\
\text { years }\end{array}$} & \multirow{2}{*}{$\begin{array}{c}\text { Sample } \\
\text { preparation }\end{array}$} & \multicolumn{2}{|c|}{$\mathbf{B e}$} \\
\hline & & & & & $\mathbf{M} \pm \mathbf{S D}$ & Range \\
\hline $\begin{array}{l}\text { Zakutinsky., et al.1962 } \\
{[29]}\end{array}$ & - & - & - & - & $<0.03$ & - \\
\hline Zaichick., et al. 2012 [39] & ICP-MS & 64 & $13-60$ & $\mathrm{AD}$ & $0.000168 \pm 0.000066$ & $0.00012-0.00044$ \\
\hline Zaichick., et al. 2013 [9] & ICP-MS & 16 & $20-30$ & $\mathrm{AD}$ & $0.00051 \pm 0.00085$ & - \\
\hline \multirow[t]{3}{*}{ Zaichick., et al. 2014 [40] } & ICP-MS & 28 & $21-40$ & $\mathrm{AD}$ & $0.000155 \pm .0 .000044$ & $0.00012-0.00031$ \\
\hline & & 27 & $41-60$ & $\mathrm{AD}$ & $0.000160 \pm .0 .000048$ & $0.00012-0.00029$ \\
\hline & & 10 & $61-87$ & $\mathrm{AD}$ & $\leq 0.00016$ & $<0.00012-0.00036$ \\
\hline Zaichick., et al. 2014 [13] & ICP-MS & 16 & $20-30$ & $\mathrm{AD}$ & $0.000162 \pm .0 .000054$ & - \\
\hline \multirow{3}{*}{ Zaichick., et al. 2014 [14] } & ICP-MS & 50 & $0-30$ & $\mathrm{AD}$ & $0.0007 \pm 0.0011$ & - \\
\hline & & 29 & $0-13$ & $\mathrm{AD}$ & $0.0013 \pm 0.0014$ & - \\
\hline & & 21 & $14-30$ & $\mathrm{AD}$ & $0.00022 \pm 0.00012$ & - \\
\hline Zaichick 2015 [41] & ICP-MS & 65 & $21-87$ & $\mathrm{AD}$ & $0.000158 \pm .0 .000054$ & - \\
\hline \multirow[t]{4}{*}{ Zaichick., et al. 2016 [42] } & ICP-MS & 28 & $21-40$ & $\mathrm{AD}$ & $0.000182 \pm 0.000085$ & - \\
\hline & & 27 & $41-60$ & $\mathrm{AD}$ & $0.000202 \pm 0.000083$ & - \\
\hline & & 10 & $61-87$ & $\mathrm{AD}$ & $0.000197 \pm 0.000133$ & - \\
\hline & & 37 & $41-87$ & $\mathrm{AD}$ & $0.000201 \pm 0.000097$ & - \\
\hline Zaichick., et al. 2016 [43] & ICP-MS & 32 & $44-87$ & $\mathrm{AD}$ & $0.000160 \pm .0 .000072$ & - \\
\hline Zaichick., et al. 2016 [44] & ICP-MS & 37 & $41-87$ & $\mathrm{AD}$ & $0.000160 \pm .0 .000073$ & - \\
\hline Zaichick., et al. 2017 [27] & ICP-MS & 37 & $41-87$ & $\mathrm{AD}$ & $0.000160 \pm .0 .000073$ & - \\
\hline Zaichick., et al. 2017 [45] & ICP-MS & 37 & $41-87$ & $\mathrm{AD}$ & $0.00019 \pm 0.00008$ & 0.00009-0.00042 \\
\hline Zaichick 2017 [46] & ICP-MS & 37 & $41-87$ & $\mathrm{AD}$ & $0.000160 \pm .0 .000060$ & $0.00012-0.00036$ \\
\hline Zaichick., et al. 2019 [47] & ICP-MS & 37 & $41-87$ & $\mathrm{AD}$ & $0.000160 \pm .0 .000060$ & $0.00012-0.00036$ \\
\hline \multicolumn{2}{|l|}{ Median of means } & \multicolumn{5}{|c|}{0.000168} \\
\hline \multicolumn{2}{|c|}{ Range of means $\left(\mathrm{M}_{\min }-\mathrm{M}_{\max }\right)$, } & \multicolumn{5}{|c|}{$<0.00012-<0.03$} \\
\hline \multicolumn{2}{|l|}{ Ratio $\mathrm{M}_{\max } / \mathrm{M}_{\min }$} & \multicolumn{5}{|c|}{$(<0.03 / 0.000155)=<194$} \\
\hline \multicolumn{2}{|l|}{ All references } & \multicolumn{5}{|c|}{14} \\
\hline
\end{tabular}

Table 1: Reference data of Be mass fractions (mg/kg wet tissue) in "normal" human prostatic tissue.

$\mathrm{M}$ - arithmetic mean, SD - standard deviation of mean, ICP-MS - inductively coupled plasma mass spectrometry, AD - acid digestion. 
Table 1 summarizes general results from the 14 publications. The retrieved studies involved 645 persons. The ages of men were available for 13 papers and ranged from 0-87 years. Information about the analytical technique and sample preparation used was available for 13 articles. In all studies Be contents were determined by inductively coupled plasma mass spectrometry (ICP-MS). The method used was the destructive analytical technique, as it needs in sample acid digestion for a measurement.

Figure 1 illustrates the data set of Be determinations in 14 studies performed from 1962 to 2020 .

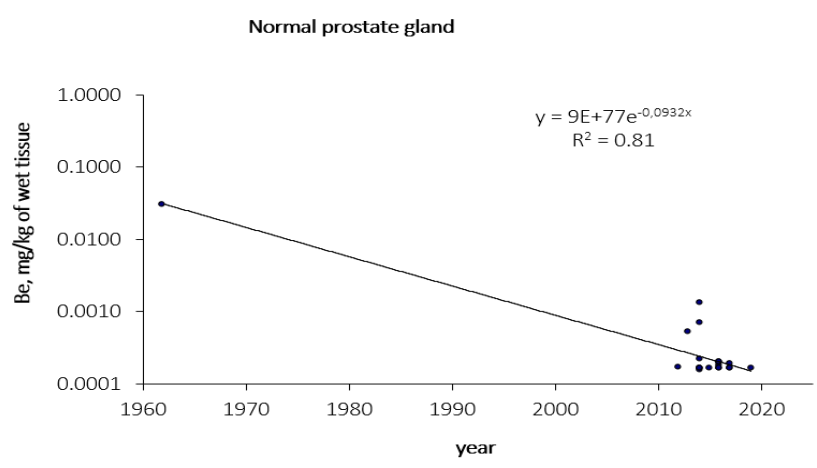

Figure 1: Data on Be content in normal prostate tissue reported from 1962 to 2020.

The range of means of Be contents published for "normal" prostate varies widely from $0.000155 \mathrm{mg} / \mathrm{kg}$ [40] to $<0.03 \mathrm{mg} / \mathrm{kg}$ [29] with median of means $0.000168 \mathrm{mg} / \mathrm{kg}$ (on a wet mass basis) (Table 1). In one study in the age group 61-87 years old persons the content of Be was quantified in a few prostates, because level of this element in all other investigated glands was under detection limit (DL) [40]. In this investigation for the group of old men the possible upper limit of the mean $(\leq M)$ for prostatic Be content was calculated as the average mass fraction, using the value of DL instead of the individual value when these latter was found below the DL:

$\leq M=\left(\sum_{i}^{n_{i}} C_{i}+D \cdot n_{j}\right) / n$ where $C_{i}$ is the individual value of Be mass fraction in $i$-sample, $n_{i}$ is number of samples with the mass fraction higher than the DL, $n_{j}$ is number of samples with the mass fraction lower than the DL, and $n=n_{i}+n_{j}$ is number of investigated samples.

This variability of reported means $(0.000155-<0.03 \mathrm{mg} / \mathrm{kg}$ of wet tissue) can be interpreted by a dependence of Be mass fraction on many factors, including analytical technology irregularity, differences in "normal" tissue definitions, age, ethnicity, diet, smoking, alcohol intake, possible inhomogeneous distribution of the metal throughout the gland volume, consuming supplemental $\mathrm{Zn}$ and Se, and others. Not all these factors were strongly controlled in the published investigations. Furthermore, the very short list of published data not allowed us to estimate the influence of all these factors on Be mass fraction in "normal" prostate.

\section{Analytical method}

The trend line of Be mass fraction data in "normal" gland (Figure 1) illustrated that an improvement of analytical techniques during last almost 60 years impacted noticeably on published results. Most probably the leading cause of inter-observer variability was a poor sensitivity of analytical methods and a lack of strong quality control of result in old study published in 1962 [29].

In all reported studies destructive analytical method ICP-MS was applied. This analytical technique needs in acid digestion of the investigated samples at a high temperature. There are distinct proofs that use of this processing causes some quantities of TEs to be lost $[35,55,56]$. And conversely, the Be content of chemicals applied for tissue decomposition can contaminate the prostatic tissue samples. Thus, when using ICP-MS with complete acid digestion of the sample, it is necessary to allow for the losses of TEs. Then there are contaminations by TEs during acid digestion of the sample, which needs in addition of some chemicals. It is possible to avoid these problems by utilizing non-destructive methods, but up to now there are no analytical techniques which allow quantify Be level in "normal" prostate without sample decomposition. It is, therefore, logically to assume that the strong quality control of results is very significant factor for using the Be level in prostate as bio-indicator.

Age

In a few studies, which applied the comparison of different age groups or the Pearson's correlation between age and Be mass frac- 
tion in prostate, it was no found a remarkable alteration of Be level with increasing age [40-42]. These facts allowed us to assume that age does not impact on the Be level of "normal" prostate gland.

\section{Androgen-independence of prostatic Be levels}

There was not found a meaningful difference between the means of prostatic Be content in the group of teenagers before puberty and the group of post-pubertal teenagers together with young adults $[9,13,14]$. These data allowed us to suppose that there are no any associations between the Be mass fraction in "normal" prostates and the level of androgens. However, publications on the correlation between the Be level in "normal" prostatic tissue and the concentration of androgens in blood were not found.

\section{Be intake}

The general population can be exposed to low levels of Be through consumption of food, ingestion of drinking water, and inhalation of ambient air [30,33,34,57]. One may also be exposed to Be through skin contact, with plastics, sports equipment, instruments, gemstones and other Be-containing things $[33,58]$. Be exposures were also reported as a result of smoking (active and passive), because Be as a chemical component, occurs naturally in tobacco and may be inhaled from cigarette smoke [30,58-60]. Another source of exposure to Be may be Be-containing dental alloys used in dental fixed prosthodontics $[61,62]$.

Be is considered as elements with an extremely high toxic potency for human and animal organisms. Moreover, Be is considered as a latent health hazard with potential risk of toxicity in humans within regions of "natural" pollution by this element [57,58,63,64]. In order to prevent Be poisoning, its content must not exceed the safe limits for food, drinking water, and air.

An average Be daily intake was estimated to be 0.005-0.100 $\mathrm{mg} /$ day [30]. Health-based guidance values used for risk characterisation of exposures to Be was accepted to be $0.002 \mathrm{mg} / \mathrm{kg}$ body weight/day [65]. Most foods have Be concentrations below 0.100 $\mathrm{mg} / \mathrm{kg}$ [30], but, for example, in New Zealand Be level in foods is almost five times lower and it does not exceed $0.022 \mathrm{mg} / \mathrm{kg}$ [66]. Be contents in dairy products, meat, poultry, eggs, vegetables, fruits and fruit juices, nuts, beverages, including vine, and other foods depend on this metal level in soil [58] and the reported mass fractions ranged from $0.001 \mathrm{mg} / \mathrm{kg}$ in soya milk to $0.022 \mathrm{mg} / \mathrm{kg}$ in salad dressing $[66,67]$. There are natural geochemical provinces with anomalous high levels of Be in soils [67] and areas with mainly anthropogenic sources of Be contamination [68]. For example, the average of Be content in U.S. soil is $0.63 \mathrm{mg} / \mathrm{kg}$ and to range from less than 1 to $15 \mathrm{mg} / \mathrm{kg}$ [30]. Marine organisms may be other dietary sources of Be [58].

Concentration of Be in waters of different types variate very widely. The average concentration in drinking water and surface water is $0.00019 \mathrm{mg} / \mathrm{L}$. and $0.0019 \mathrm{mg} / \mathrm{L}$, respectively [30]. Average concentrations of Be in U.S. tap water and bottled water are determined to be 0.013 and less than $0.1 \mu \mathrm{g} / \mathrm{L}$, respectively [30] At present, no health-based guideline values exist for Be in drinking and tap water [58].

Be concentration in air can be traced from atmospheric deposition and it is varied very widely. For example, data on the average Be concentration in air of UK published in 2016 (0.00787 ng/ m3) [69] are four times lower than the average concentration of Be in air of the United States $(0.03 \mathrm{ng} / \mathrm{m} 3)$ [30]. In air of U.S. cities the average concentration of Be was almost one order of magnitude higher (0.2 ng/m3) [30]. However, in air of some workplaces the Be concentration can be more than four orders of magnitude higher than this value [58].

Other potential sources of Be exposure include active and passive tobacco smoking. Be presents in cigarette smoke and poses health threats to the life of smokers as a result of direct inhalation and at the same time elevates health risks to non-smokers present in the vicinity of smokers [60]. Range of this metal mass fraction reported in cigarette tobacco produced in U.S. was estimated to be 0.016-0.017 mg/kg tobacco [59].

Furthermore, over the last decades the use of Be-containing dental alloys in dental fixed prosthodontics, has created an entirely new source of internal Be exposure [61,62]. Corrosion and wear produce soluble metal ions and metal debris in the form of huge numbers of wear nanoparticles, with systemic dissemination in human body.

Aside from the naturally occurring sources, exposure of people to Be is limited to inhalation and dermal contact during occupational processes. The exposures occur mainly during production of Be pure metal, Be oxide and an alloy with copper, aluminum, or nickel [70]. 


\section{Be content in body fluids, tissues and organs}

The total content of Be in the body of adults is about $0.036 \mathrm{mg}$ [71]. A quarter of this amount (about $0.009 \mathrm{mg}$ ) is located in the skeleton, which is the major storage pool for long-term Be accumulation $[30,71]$. Among soft tissues of human body principle organs of Be retention are lung, lymph nodes, liver, and kidneys [71-73]. Information on Be content in human organs and tissues is very limited. Baumgardt., et al. reported range of Be contents (0.0003$0.0045 \mathrm{mg} / \mathrm{kg}$ of wet tissue) in the 125 samples of lung which were obtained from the subjects exposed only to environmental levels [74]. Reported Be levels in whole blood of healthy persons 0.00048-0.00071 mg/L [75] are below data for Reference Man $(0.001 \mathrm{mg} / \mathrm{L})$ [30]. In recent study the mean Be content in blood plasma was estimated to be $0.00007 \pm 0.00003 \mathrm{mg} / \mathrm{L}$ [76]. Since the median of prostatic Be content means obtained in the present study ( $0.000168 \mathrm{mg} / \mathrm{kg}$ of wet tissue) almost equals the metal level in lung and more than two times higher the blood plasma level, we can conclude that the prostate gland is also a target organ for Be.

Be, as all other natural chemical elements of the Periodic System, presents in all components and objects of biosphere $[35,77,78]$. During the long evolutional period the Be intakes in organisms were more or less stable and organisms were adopted for such environmental conditions, but, as was mentioned above, until now there are no data on any biological function of Be in organisms [79]. The situation with Be presence in biosphere began to change after the industrial revolution, especially over the last 100 years. Although Be was discovered in 1798, it only became commercially significant in the 1920s [80]. Be is lighter than aluminum and six times stronger than stainless steel [80]. Because of its strength, electrical and thermal conductivity, corrosion resistance, and nuclear properties, Be products are applied in the sphere of the nuclear weapons, aerospace, and atomic energy, as well as in automotive, electronics, and medical industries [63].

Be as pure metal is used to make components in aircraft, X-ray equipment, space optics and precision instruments, satellite structures, missile parts, neutron reflectors, nuclear weapons, fuel containers, rocket propellants, navigational systems, heat shields, mirrors, high-speed computers, audio components, and is also used as an acid catalyst in organic reactions [58]. Be compounds are used to produce Be metal and Be-containing alloys with cooper (4$4.25 \% \mathrm{Be}$ ), aluminum (20-60\% Be) and nickel, in nuclear reactors, high-temperature reactor systems, glass-making, high-technology ceramics, electronic heat sinks, electrical insulators, microwave oven components, gyroscopes, military vehicle armor, rocket nozzles, crucibles, nuclear reactor fuels, thermocouple tubing, lasers, high-density electrical circuits, automotive ignition systems, and as a catalyst for organic reactions, an additive to glass, ceramics, and plastics, construction materials for automobiles, computers, sports equipment (e.g., golf clubs and bicycle), dental bridges, springs, nonsparking tools, submarine cable housings and pivots, wheels, pinions, telecommunications devices etc. [58].

Thus, metallic Be, Be-contained alloys and Be compounds are ubiquitously distributed in environment and food, water, and air everywhere contain this element. Besides the abundant natural sources of $\mathrm{Be}$, there are a large number of industrial producers of Be to the soil (through atmospheric emissions originating from residues from coal, oil, and gas combustion, power plants, aluminum and other non-ferrous metal production, urban refuse, mine tailings, smelter slag, waste), water (through irrigation and industrial liquid waste, livestock dips, and wastewater sludge application), and air (Be may be released from residues from coal, oil, gas and waste combustion, power plants, aluminum and other nonferrous metal production, urban refuse, mine tailings, smelter slag) contamination $[33,34,58,70]$. The anthropogenic emission of Be was estimated as 187 tons annually [33,34]. Interestingly remark, that natural sources of Be release to the atmosphere, such as windblown dust and volcanic particles, are estimated to account for 5.2 tons per year, or $2.6 \%$ of total emissions [33]. From the polluted environment this metal is subsequently introduced into the food chain and for the general population, the food is the main source of exposure to $\mathrm{Be}[33,34,58,70]$.

Be is an important product in the world industry. The world production of Be in 2019 was estimated to be 260 tons [81]. The world's largest producers are U.S. (170 tons) and China (70 tons). Since the use of Be is linked to the rapidly developing modern technologies, we can suppose that over the years, the need of industry in this metal and its components has increased significantly and would continue to increase in the future. Some estimates expect demand to grow to over 450 tons by 2030 .

As was mentioned above, an ingestion or inhalation of Be low dose by humans can cause a variety of disorders. Acutely it causes 
such disorders as pneumonitis, cough, chest pain, dyspnea, pneumonia, conjunctivitis, rhinitis, pharyngitis and others [58]. Chronically, it results in sarcoid-like granulomata mainly in the lungs (chronic beryllium disease) and is occasionally subcutaneous [58,63,70,82]. Furthermore, as was shown in the experimental studies, Be and Be compounds are cytotoxic and genotoxic [21,30,31,33,34]. Moreover, an increase in potential risk of lung cancer and tumors of the central nervous system was observed among workers exposed to Be $[20,32,64]$. Precise molecular mechanisms by which this metal causes healthy cells to transform to malignant states have yet to be fully defined $[21,31,38,83]$.

Thus, for unpolluted regions, according our systematic review, there are no information could explain the variability of reported means for "normal" prostatic Be content from $0.000155 \mathrm{mg} / \mathrm{kg}$ to $<0.03 \mathrm{mg} / \mathrm{kg}$ of wet tissue. Moreover, prostatic Be contents demonstrated large variations among individuals, but reasons of these variation remain unknown. It is, therefore, reasonable to assume from results of our review that inaccuracy of analytical techniques employed caused so great variability of reported means for prostatic Be contents. This conclusion was supported the fact that the Certified Reference Materials for quality control of results were not applied in old investigations, which data were reflected by Zakutinsky., et al. [29].

There are some limitations in our review, which need to be taken into consideration when interpreting the obtained results. The sample size of each reported investigation was sometimes relatively small (from 10 to 65), and a total of 645 "normal" prostate glands were analyzed from all 14 articles. As such, it is difficult to draw definite conclusions about the reference value of the Be level in "normal" prostate as well as about the clinical value of the Be content in "normal" prostates as a bio-indicator.

\section{Conclusion}

The present systematic review is a comprehensive study regarding the determination of Be content in "normal" human prostates. With this knowledge Be levels may then be considered as a bio-indicator for the recognition of prostate disorders and primary such as PCa. The review has demonstrated that value of Be content in "normal" prostates depends on many unknown factors. Because of the uncertainties we have outlined, we recommend other primary studies with the strong quality control of results be performed.

\section{Conflict of interest}

The author declares that there no conflict of interest.

\section{Bibliography}

1. Nickel JC. "Prostatitis". Canadian Urological Association Journal 5.5 (2011): 306-315.

2. Lim KB. "Epidemiology of clinical benign prostatic hyperplasia”. Asian Journal of Urology 4.3 (2017): 148-151.

3. Rawla P. "Epidemiology of Prostate Cancer". World Journal of Oncology 10.2 (2019): 63-89.

4. Avisyn AP., et al. Histological structure of the prostate and content of zinc in it during various age period. Archiv Anatomy, Gistology, and Ebriology (Leningrad) 81.11 (1981): 76-83.

5. Zaichick V. "INAA and EDXRF applications in the age dynamics assessment of $\mathrm{Zn}$ content and distribution in the normal human prostate". Journal of Radioanalytical and Nuclear Chemistry 262 (2004): 229-234.

6. Zaichick V and Zaichick S. "The effect of age on $\mathrm{Br}, \mathrm{Ca}, \mathrm{Cl}, \mathrm{K}, \mathrm{Mg}$, $\mathrm{Mn}$, and Na mass fraction in pediatric and young adult prostate glands investigated by neutron activation analysis". Applied Radiation and Isotopes 82 (2013): 145-151.

7. Zaichick V and Zaichick S. "INAA application in the assessment of $\mathrm{Ag}, \mathrm{Co}, \mathrm{Cr}, \mathrm{Fe}, \mathrm{Hg}, \mathrm{Rb}, \mathrm{Sb}, \mathrm{Sc}$, Se, and $\mathrm{Zn}$ mass fraction in pediatric and young adult prostate glands". Journal of Radioanalytical and Nuclear Chemistry 298 (2013): 1559-1566.

8. Zaichick V and Zaichick S. "NAA-SLR and ICP-AES Application in the assessment of mass fraction of 19 chemical elements in pediatric and young adult prostate glands". Biological Trace Element Research 156 (2013): 357-366.

9. Zaichick V and Zaichick S. "Use of neutron activation analysis and inductively coupled plasma mass spectrometry for the determination of trace elements in pediatric and young adult prostate". American Journal of Analytical Chemistry 4 (2013): 696-706.

10.Zaichick V and Zaichick S. "Relations of bromine, iron, rubidium, strontium, and zinc content to morphometric parameters in pediatric and nonhyperplastic young adult prostate glands". Biological Trace Element Research 157 (2014): 195-204. 
11.Zaichick V and Zaichick S. "Relations of the neutron activation analysis data to morphometric parameters in pediatric and nonhyperplastic young adult prostate glands". Advances in Biomedical Science and Engineering 1.1 (2014): 26-42.

12.Zaichick V and Zaichick S. "Relations of the $\mathrm{Al}, \mathrm{B}, \mathrm{Ba}, \mathrm{Br}, \mathrm{Ca}, \mathrm{Cl}$, $\mathrm{Cu}, \mathrm{Fe}, \mathrm{K}, \mathrm{Li}, \mathrm{Mg}$, Mn, Na, P, S, Si, Sr, and Zn mass fractions to morphometric parameters in pediatric and nonhyperplastic young adult prostate glands". BioMetals 27 (2014): 333-348.

13.Zaichick V and Zaichick S. "Androgen-dependent chemical elements of prostate gland". Andrology and Gynecology: Current Research 2 (2014): 2.

14.Zaichick V and Zaichick S. "The distribution of 54 trace elements including zinc in pediatric and nonhyperplastic young adult prostate gland tissues". Journal of Clinical and Laboratory Investigation Updates 2.1 (2014): 1-15.

15.Zaichick V and Zaichick S. "Differences and relationships between morphometric parameters and zinc content in nonhyperplastic and hyperplastic prostate glands". British Journal of Medicine and Medical Research 8.8 (2015): 692-706.

16. Schwartz MK. "Role of trace elements in cancer". Cancer Research 35 (1975): 3481-3487.

17. Zaichick V and Zaichick S. "Role of zinc in prostate cancerogenesis". In: Mengen und Spurenelemente Arbeitstagung. Jena: Friedrich-Schiller-Universitat 19 (1999): 104-115.

18. Zaichick V., et al. "Intracellular zinc excess as one of the main factors in the etiology of prostate cancer". Journal of Analytical Oncology 5.3 (2016): 124-131.

19.Zaichick V., et al. "Intracellular calcium excess as one of the main factors in the etiology of prostate cancer". AIMS Molecular Science 3 (2016): 635-647.

20. Fukuda H., et al. "Trace elements and cancer". Japan Medical Association Journal 47.8 (2004): 391-395.

21. Chen QY., et al. "Metals and Mechanisms of Carcinogenesis". Annual Review of Pharmacology and Toxicology 59 (2019): 537554.

22. Dunchik V., et al. "Method for differential diagnostics of prostate malignant and benign tumours". Russian patent (Author's Cer- tificate No 764660, priority of invention 27.10.1977). Discoveries, Inventions, Commercial Models, Trade Marks 35 (1980): 13.

23.Zaichick V., et al. "Zinc in the human prostate gland: normal, hyperplastic and cancerous". International Urology and · Nephrology 29 (1997): 565-574.

24. Zaichick V., et al. "Zinc in human prostate gland: normal, hyperplastic and cancerous". Journal of Radioanalytical and Nuclear Chemistry 217 91997): 157-161.

25. Zaichick S and Zaichick V. "Trace elements of normal, benign hypertrophic and cancerous tissues of the human prostate gland investigated by neutron activation analysis". Applied Radiation and Isotopes 70 (2012): 81-87.

26. Zaichick V and Zaichick S. "Ratios of selected chemical element contents in prostatic tissue as markers of malignancy". Hematology and Medical Oncology 1.2 (2016): 1-8.

27.Zaichick V and Zaichick S. "Trace element levels in prostate gland as carcinoma's markers". Journal of Cancer Therapy 8 (2017): 131-145.

28.Zaichick V and Zaichick S. "Ratios of Zn/trace element contents in prostate gland as carcinoma's markers". Cancer Reports and Reviews 1.1 (2017): 1-7.

29. Zakutinsky DI., et al. "Data book on the radioactive isotopes toxicology". Moscow: State Publishing House of Medical Literature (1962)

30. ATSDR, Agency for Toxic Substances and Disease Registry. Public health statement. Beryllium. Cas\#: 7440-41-7. Buford Highway, Atlanta, Georgia, USA (2008): 1-7.

31. Léonard A and Lauwerys R. "Mutagenicity, carcinogenicity and teratogenicity of beryllium. Mutation Research/Reviews in Genetic Toxicology 186.1 (1987): 35-42.

32. Hollins DM., et al. "Beryllium and lung cancer: a weight of evidence evaluation of the toxicological and epidemiological literature". Critical Reviews in Toxicology 39 (2009): 1-32.

33. WHO, World Health Organization. "Beryllium and beryllium compounds". Concise International Chemical Assessment Document 32. Geneva (2001). 
34. US EPA, US Environmental Protection Agency. "Toxicological review of beryllium and compounds (CAS No. 7440-41-7)". In support of summary information on the Integrated Risk Information System (IRIS). Washington, DC: US EPA (1998).

35. Zaichick V. "Medical elementology as a new scientific discipline". Journal of Radioanalytical and Nuclear Chemistry 269 (2006): 303-309.

36. Hunter P. "A toxic brew we cannot live without. Micronutrients give insights into the interplay between geochemistry and evolutionary biology". EMBO Reports 9.1 (2008): 15-18.

37. López-Alonso M. “Trace minerals and livestock: Not too much not too little". International Scholarly Research Notices 2012 (2012).

38. Zhu Y and Costa M. "Metals and molecular carcinogenesis". Carcinogenesis 41.9 (2020): 1161-1172.

39. Zaichick S., et al. "Mass fractions of 52 trace elements and zinc trace element content ratios in intact human prostates investigated by inductively coupled plasma mass spectrometry". Biological Trace Element Research 149 (2012): 171-183.

40.Zaichick V and Zaichick S. "Use of INAA and ICP-MS for the assessment of trace element mass fractions in adult and geriatric prostate". Journal of Radioanalytical and Nuclear Chemistry 301 (2014): 383-397.

41. Zaichick V. "The variation with age of 67 macro- and microelement contents in nonhyperplastic prostate glands of adult and elderly males investigated by nuclear analytical and related methods". Biological Trace Element Research 168 (2015): 4460.

42. Zaichick V and Zaichick S. "Age-related changes in concentration and histological distribution of 54 trace elements in nonhyperplastic prostate of adults". International Archives of Urology and Complications 2.2 (2016): 019.

43. Zaichick V and Zaichick S. "Levels of 43 trace elements in hyperplastic human prostate". British Journal of Medicine and Medical Research 15.2 (2016): 1-12.

44. Zaichick V and Zaichick S. "Prostatic tissue levels of 43 trace elements in patients with prostate adenocarcinoma". Cancer and Clinical Oncology 5.1 (2016): 79-94.
45. Zaichick V and Zaichick S. "Chemical element contents in normal and benign hyperplastic prostate". Annals of Mens Health and Wellness 1.2 (2017): 1006.

46. Zaichick V. "Differences between 66 chemical element contents in normal and cancerous prostate". Journal of Analytical Oncology 6 (2017): 37-56.

47. Zaichick V and Zaichick S. “Comparison of 66 chemical element contents in normal and benign hyperplastic prostate. Asian Journal of Urology 6 (2019): 275-289.

48. Isaacs JT. "Prostatic structure and function in relation to the etiology of prostatic cancer". Prostate 4.4 (1983): 351-366.

49. Leissner KM., et al. "Concentration and content of zinc in human prostate". Investigative Urology18 (1980): 32-35.

50. Woodard HQ and White DR. "The composition of body tissues". British Journal of Radiology 59 (1986): 1209-1218.

51. Arnold WN. And Thrasher JB. "Selenium concentration in the prostate". Biological Trace Element Research 91.3 (2003): 277280 .

52. Tipton IH and Cook MJ. "Trace elements in human tissue. Part II. Adult subjects from the United States". Health Physics 9.2 (1963): 103-145.

53. Schroeder HA., et al. "Essential trace metals in man: Zinc. Relation to environmental cadmium". Journal of Chronic Diseases 20 (1967): 179-210.

54. Saltzman BE., et al. "Total body burdens and tissue concentrations of lead, cadmium, copper, zinc, and ash in 55 human cadavers". Environmental Research 52 (1990): 126-145.

55. Zaichick V. "Sampling, sample storage and preparation of biomaterials for INAA in clinical medicine, occupational and environmental health". In: Harmonization of Health-Related Environmental Measurements Using Nuclear and Isotopic Techniques. Vienna: IAEA (1997): 123-133.

56. Zaichick V. "Losses of chemical elements in biological samples under the dry aching process". Trace Elements in Medicine 5.3 (2004): 17-22.

57. Taylor TP., et al. "Beryllium in the environment: a review". Journal of Environmental Science and Health, Part A. Toxic/Hazard- 
ous Substances and Environmental Engineering 38.2 (2003): 439-469.

58. Cooper RG and Harrison AP. "The uses and adverse effects of beryllium on health". Indian Journal of Occupational and Environmental Medicine 13.2 (2009): 65-76.

59. Pappas RS. "Toxic elements in tobacco and in cigarette smoke: Inflammation and sensitization". Metallomics 3.11 (2011): 1181-1198.

60. Behera SN., et al. "Human health risk associated with exposure to toxic elements in mainstream and sidestream cigarette smoke. Science of the Total Environment 472 (2014): 947-56.

61. Elshahawy W and Watanabe I. "Biocompatibility of dental alloys used in dental fixed prosthodontics". Tanta Dental Journal 11.2 (2014): 150-159.

62. Stark M., et al. "Biological exposure metrics of beryllium-exposed dental technicians". Archives of Environmental and Occupational Health 69.2 (2014): 89-99.

63. Kolanz ME. "Introduction to beryllium: uses, regulatory history, and disease". Applied Occupational and Environmental Hygiene 16.5 (2001): 559-567.

64. Schubauer-Berigan MK., et al. "Risk of lung cancer associated with quantitative beryllium exposure metrics within an occupational cohort". Occupational and Environmental Medicine 68.5 (2011): 354-360.

65. WHO, World Health Organization. Beryllium in drinking water. Background document for preparation of WHO Guidelines for drinking-water quality. Geneva (Switzerland): WHO (2009).

66. Pearson AJ and Ashmore E. "Risk assessment of antimony, barium, beryllium, boron, bromine, lithium, nickel, strontium, thallium and uranium concentrations in the New Zealand diet". Food Additives and Contaminants: Part A 37.3 (2020): 451-464.

67. Kleyn SV., et al. "The influence of natural geochemical provinces on the drinking water quality and the public health risk formation". Earth and Environmental Science 548 (2020): 062081.

68. Smithwick RW., et al. "Beryllium characterization in soils by selective extraction". Talanta 223.1 (2021): 121742.
69. Goddard SL., et al. "Determination of beryllium concentrations in UK ambient air". Atmospheric Environment 147 (2016): 320329.

70. Strupp C. "Beryllium metal II. A review of the available toxicity data". Annals of Occupational Hygiene 55.1 (2011): 43-56.

71. ICRP. International Commission for Radiation Protection. Report of the task group on reference man. ICRP Publication No. 23. New York: Pergamon Press (1975).

72. Mcguigan MA. "Chronic poisoning: Trace metals and others". In: Goldman's Cecil Medicine (Twenty-Fourth Edition). Elsevier 1 (2012): 88-95.

73. Jakubowski M and Pałczynski C. "Beryllium" (Chapter 30). In: Handbook on the Toxicology of Metals (Fourth Edition). Academic Press 2 (2015): 635-653.

74. Baumgardt B., et al. "Trace analysis to determine heavy metal load in lung tissue". International Archives of Occupational and Environmental Health 58 (1986): 27-34.

75. Stephan GH., et al. "Graphite furnace atomic absorption spectrometry as a routine method for the quantification of beryllium in blood and serum". Chemistry Central Journal 2 (2008): 14.

76. Barrientos G., et al. "Association between trace elements and body composition parameters in endurance runners". International Journal of Environmental Research and Public Health 17.18 (2020): 6563.

77. Vernadsky VI. “Living Matter”. Moscow: Nauka (1978).

78. Zaichick V., et al. "Medical elementology: a new scientific discipline". Trace Elements and Electrolytes 24.2 (2007): 69-74.

79. Chellan P and Sadler PJ. "The elements of life and medicines". Philosophical Transactions A: Mathematical, Physical and Engineering Sciences 373.2037 (2015): 20140182.

80. Gad SC. "Beryllium". In: Encyclopedia of Toxicology (Third Edition). Elsevier (2014): 435-437.

81. Garside M. "World beryllium mine production by major countries 2015-2019". (2020). 
82. Sprince NL, et al. "Current (1975) problem of differentiating between beryllium disease and sarcoidosis". Annals of the New York Academy of Sciences 278 (1976): 654-664.

83. Tokar EJ., et al. "Metal ions in human cancer development". Metal Ions in Life Sciences 8 (2011): 375-401.

\section{Assets from publication with us}

- Prompt Acknowledgement after receiving the article

- Thorough Double blinded peer review

- Rapid Publication

- Issue of Publication Certificate

- High visibility of your Published work

Website: www.actascientific.com/

Submit Article: www.actascientific.com/submission.php

Email us: editor@actascientific.com

Contact us: +919182824667 